\title{
PENDIDIKAN AGAMA ISLAM SEBAGAI BEKAL MORAL DALAM KEHIDUPAN BERNEGARA
}

\author{
Isnawati Nur Afifah Latif \\ Pendidikan Agama Islam, Tarbiyah, Institut Agama Islam Nahdlatul Ulama Tuban \\ Email :Isnawatinurafifahlatif@gmail.com
}

\begin{abstract}
Abstrak
Pendidikan Agama Islam bertujuan membentuk generasi berakhlak mulia. Pancasila adalah dasar negara Indonesia dengan sila pertama menyebutkan Ketuhanan Yang Maha Esa. Hal ini menunjukkan bahwa negara ini menghormati Agama. Berdasar hal ini, Pendidikan Agama Islam sebagai pembentuk moral generasi Indonesia, yang merupakan generasi mayoritas. Indonesia bukan negara agama, tetapi menempatkan Ketuhanan Yang Maha Esa di urutan prioritas. Penelitian ini menggunakan metode kualitatif dengan pendekatan kajian literatur. Peneliti menemukan bahwa negara sekuler pun menempatkan pendidikan Agama, menjalani keyakinan dan kepercayaan sebagai bekal penting warganegaranya, dan dijamin oleh hukum negara. Agama, keyakinan, kepercayaan mempengaruhi psikologis dan kualitas individu yang berpengaruh pada kemajuan negara. Mengikuti penjelasan di atas/sebelumnya, Sistem Pendidikan Nasional menjadi pedoman pelaksanaan Pendidikan Agama Islam, sehingga output pendidikan yang ditarget sesuai dengan tujuan negara Indonesia. Kemudian keberadaan Kurikulum penting mengarahkan keberlangsungan Pendidikan Nasional tersebut.
\end{abstract}

Kata Kunci: Moral, Pancasila, Agama, Kepercayaan, Pendidikan Nasional.

\section{PENDAHULUAN}

Pendidikan di Indonesia memiliki sejarah panjang dengan latar belakang kemajemukan etnis, sejarah budaya, sosial politik dan keagamaan. Jika dirunut dari sejarah awal pendidikan di Indonesia, maka terkhusus Pendidikan Agama Islam merupakan produk bernegara dalam rangka menciptakan generasi Indonesia yang memahami cita-cita luhur negaranya. Cita-cita ini termaktub dalam Pembukaan Undang-Undang Dasar Negara Republik Indonesia tahun 1945 alenia 4 yaitu mencerdaskan kehidupan bangsa. Pendidikan Agama Islam merupakan salah satu mata pelajaran dari banyak mata pelajaran yang diberikan selama jenjang Sekolah Dasar dan Sekolah Menengah yang dilalui siswa selama 12 tahun menempuh pendidikan, sebelum pendidikan tinggi. Pendidikan Agama menjadi penting karena sebagai penuntun dan pembentuk individu yang kemudian memberi pengaruh pada kehidupan bermasyarakat dan bernegara. Di sisi lain Islam sendiri merupakan Agama dengan pemeluk mayoritas sehingga memberi warna dominan perilaku kehidupan pemeluknya yang sekaligus warga negara Indonesia. Oleh karena itu Pendidikan Agama Islam menempati posisi penting untuk membentuk karakter bernegara. Karakter muslim yang membela negaranya oleh Supriadi (2015), dijelaskan sebagai bagian dari tanggungjawab nilai-nilai keislaman yaitu bagian dari cinta tanah air yang merupakan perintah agama Islam. 
Keberhasilan dalam Pendidikan Agama Islam salah satunya ditentukan oleh kurikulum. Kurikulum sebagai penunjuk penting untuk keberhasilan mencapai tujuan bagi siswa yang menempuh Pendidikan Agama Islam. Tetapi sayangnya, kurikulum sering berubah-berubah dengan berubahnya perpolitikan di Indonesia.

Kurikulum diartikan sebagai satu kesatuan rencana dan tata cara mengenai bahan pengajaran yang kemudian dipakai sebagai panduan kegiatan belajar mengajar. Hidayati (2016) mengutip dari Omar Mohammad Al-Taoumy Al-Syaibany penggunaan istilah yang diambil dari bahasa Arab Manhaj yang berarti jalan benderang, diperuntukkan kata kurikulum pendidikan tentang makna kata kurikulum pendidikan.

Indonesia dengan masyarakat majemuk yang berasal dari berbagai suku bangsa dan daerah, sehingga Pendidikan Agama Islam yang diberikan kepada berbagai asal sekolah yang berbeda semestinya mengedepankan kearifan lokal. Perencanaan kurikulum yang dilakukan oleh pusat kementrian di ibu kota Jakarta kemudian digunakan sebagai acuan oleh sekolah-sekolah di seluruh wilayah Indonesia. Tim-tim yang dibentuk sudah dianggap sebagai perwakilan dari berbagai komponen pendidik dan ahli pendidikan.

Pelupessy-Wowor (2016) memaparkan bahwa aturan dalam Pendidikan Agama sangat penting karena kemajemukan masyarakat Indonesia. Pendidikan Agama secara signifikan mempengaruhi cara berpikir masyarakat mengenai hak-hak mencapai kebebasan atau Hak Asasi Manusia. Melalui proses pendidikan ini maka komunitas akan saling belajar untuk saling menghormati.

Penelitian ini meneliti tentang perencanaan Kurikulum Pendidikan Agama Islam yang mempunyai peran penting, sehingga perencanaan Kurikulum semestinya dilakukan dengan matang berdasar kemajemukan masyarakat Indonesia. Kurikulum tersebut nantinya sesuai dan bisa diterapkan oleh semua sekolah di seluruh daerah Indonesia yang beraneka dalam suku dan budaya. Berikut beberapa penelitian tentang kurikulum. Sya'bani (2018) meneliti tentang pengembangan kurikulum Pendidikan Agama Islam dalam Persfektif Pendidikan Nilai. Tujuan yang diharapkan yaitu siswa akan memiliki nilai diri yang meningkat kemudian diamalkan dalam kehidupan masyarakat di lingkup mereka berada. Kurikulum pengajaran terus dikembangkan sesuai de ngan kebutuhan siswa dan perkembangan jaman. Kemudian Hidayati (2016) meneliti tentang Manajemen Kurikulum Pendidikan Agama Islam dan Budi Pekerti Jenjang SMA Bermuatan Keilmuan Integrasi Interkoneksi. Dipaparakan bahwa diperlukan menejemen kurikulum dengan saling terhubung dan terintegrasi sehingga mulai dari perencanaan, pengorganisasian, penerapan, dan pengawasan kurikulum merupakan satu kesatuan utuh untuk mencapai tujuan terbaik terhadap proses pendidikan. Sedangkan Hasan (2017) melakukan penelitian berjudul Pengembangan 
Kurikulum Pendidikan Agama Islam Terpadu di Sekolah, yang menjelaskan peran pengembangan kurikulum dari suatu ide kemudian dikembangan dalam arsip perencanaan kurikulum selanjutnya pelaksanaan kurikulum dalam proses akademik.

Mengingat sejarah kurikulum yang panjang membuktikan bahwa pendidikan di Indonesia sebagai kunci perubahan dan kemajuan bangsa. Menurut penelitian Dhaifi (2017), kurikulum secara formal di berlakukan pada tahun 1950, meskipun 1947 sudah berusaha diterapkan tetapi masih dominan dengan pola pendidikan ala Jepang dan Belanda. Meskipun pada 1946 pembelajaran Agama berusaha dilaksanakan berdasarkan Surat Keputusan Bersama (SKB) dua menteri yaitu Menteri Pendidikan dan Pengajaran (PP) dan Menteri Agama. Kemudian pada 1951 ditegaskan melalui SKB 2 menteri tersebut untuk mewajibkan Pendidikan Agama di sekolah-sekolah, dengan lama waktu paling sedikit 2 jam tiap minggu.

Penelitian ini mengambil tema yang ditujukan pada keragaman atau kemajemukan (diversity) karena isu-isu budaya dan suku seringkali timbul tenggelam dalam masyarakat Indonesia. Isu-isu terkait suku, ras dan agama seringkali mengaraha pada bentrok fisik. Berdasar berbagai kejadian dan fenomena di masayarakat maka peran sekolah dengan sistemnya menjadi harapan kebaikan bagi masyarakat. Selain hal tersebut siswa-siswa sekolah merupakan generasi muda dan paling rentan terhadap hasutan terkait suku, ras dan budaya. Berdasar hal tersebut penelitian tentang kurikulum dengan perencanaan berbasisr pada kemajemukan masyarakat Indonesia sangat penting. Nilai-nilai kemajemukan yang diajarkan kepada siswa melalui kurikulum akan berdampak pada kerukunan antar suku dan ras di masyarakat. Penyampaian oleh guru akan terarah dengan kurikulum yang matang.

\section{KAJIAN TEORI}

\section{Negara Majemuk}

Indonesia sebagai negara majemuk terdiri beragam suku bangsa mempunyai Pancasila sebagai dasar negara. Pancasila dengan lima sila yang menjadi pedoman nilai kehidupan masyarakat Indonesia yaitu, Ketuhanan Yang Maha Esa, Kemanusiaan yang Adil dan Beradap, Persatuan Indonesia, Kerakyatan yang Dipimpin oleh Hikmat dalam Pemusyawaratan Perwakilan dan Keadilan Sosial bagi Seluruh Rakyat Indonesia. Kelima sila ini menjadi dasar kehidupan negara yang saling mendukung dan tidak terpisah-pisah dalam pengamalannya. Nilai luhur Pancasila ini diinternalisasi pada setiap warganegara salah satunya melalui sistem pendidikan. Pendidikan Agama Islam merupakan bagian dari sistem pendidikan Indonesia gambaran Pancasila sila pertama, Ketuhanan Yang Maha Esa. Tentu saja sila-sila yang lain sebagai pendukung penting karena merupakan bagian dari kesatuan Pancasila. 
Peranan Pendidikan Agama Islam menjadi penting karena pembentukan Pancasila yang disepakati oleh perwakilan masyarakat Indonesia pada awal kemerdekaan Indonesia menetapkan sila 1 (pertama) yaitu Ketuhanan Yang Maha Esa sebagai urutan pertama. Urutan Pancasila ini sebagai kesepakatan dari berbagai perwakilan masyarakat Indonesia pada saat awal kemerdekaan tahun 1945 melalui sidang Badan Penyelidik Usaha-Usaha Persiapan Kemerdekaan Indonesia (BPUPKI) selain pemilihan bentuk negara sebagai Republik. Berketuhanan menjadi hal dasar kehidupan berbangsa sebagai gambaran negara majemuk dengan beragam agama. Mengingat penduduk Indonesia adalah mayoritas muslim selanjutnya diikuti agama Kristen, Buda, Hindu dan kepercayaan lain. Keberagaman keyakinan ini telah mendidik masyarakat untuk saling menghormati dalam keseharian. Sebagai mayoritas tentunya pemeluk agama Islam memegang peranan mayoritas menjaga kerukunan bernegara. Meski pun Islam secara resmi bukan merupakan agama negara di Indonesia, seperti halnya Malaysia yang menjadikan Agama Islam secara resmi sebagai Agama Negara (Syah, 2016: 82; 105). Pendidikan faktanya cenderung mengarahkan kepada kemampuan intelektual atau intelectual quotion (IQ), padahal selain kemampuan intelektual mumpuni kecerdasan emosional juga sama pentingnya. Kecerdasan emosional ini di dalamnya terkait dengan akhlak mulia. Oleh karena itu kebutuhan mendesak negara Indonesia adalah mencetak generasi Indonesia yang seimbang dalam intelectual quotion (IQ) dan emotional quotion (EQ).

\section{Nilai-nilai Pendidikan Agama Islam}

Nilai-nilai Islam penting dalam mempengaruhi perilaku pemeluknya (Zamri, 2019). Pendidikan Agama Islam sebagai salah satu cara negara mendidik pemeluknya melalui sistem pendidikan yang dilindungi oleh negara. Keyakinan terhadap Tuhan kemudian dilanjutkan dengan mengamalkan ajaran Tuhan dimasukkan dalam sistem Pendidikan Indonesia melalui mata pelajaran Pendidikan Agama. Terkhusus dalam bahasan ini adalah Pendidikan Agama Islam. Oleh karenanya Pendidikan Agama Islam yang mengajarkan nilai luhur hidup berdampingan dengan sesama manusia dan lingkungan lain seperti hewan, tumbuhan dan alam sekitar. Sehingga akhirnya tercipta keseimbangan kehidupan di masyarakat dan alam semesta. Akhirnya tujuan dari ajaran Islam yang Rahmatilil alamin (membawa kebaikan untuk Alam semesta beserta isinya) tercapai.

Pendidikan digariskan sesuai dengan amanat Undang-undang 1945 untuk mencerdaskan kehidupan bangsa. Meskipun pada pelaksaannya masih menjadi tantangan untuk memeratakan kualitas pendidikan di segenap sudut wilayah Indonesia dari Sabang hingga Merauke. Sistem Pendidikan Agama diatur pada Undang-Undang Nomor 2 tahun 1989 tentang Pendidikan Nasional juncto Undang-Undang Nomor 20 tahun 2003 tentang tujuan Pendidikan Nasional, penegembangan muatan kurikulum, dan hak peserta didik. Tujuan dan fungsi Pendidikan Agama Islam Indonesia 
yang dijabarkan melalui Undang-Undang Sistem Pendidikan Nasional UU nomor 20 tahun 2003 yaitu, membentuk dan mengembangkan karakter dan peradaban bangsa dalam konteks intelektual yang bertujuan mengembangkan potensi siswa untuk menjadi orang beriman, dan memiliki rasa takut akan Tuhan Yang Maha Esa (UU Nomor 20 tahun 2003 dalam Mu'ti, 2016).

\section{Tujuan Pendidikan Agama Islam}

Tujuan-tujuan mulia pembentuk karakter bernegara tersebut salah satunya diamanatkan ke sekolah melalui Pendidikan Agama Islam. Sekolah mempunyai kurikulum yang terus dipantau dan diperbaiki dengan beragam indikator keberhasilan. Proses menjadi harapan besar untuk menciptakan generasi bermoral yang akan mengemban tugas mulia sebagai generasi penerus Indonesia. Moral sebagai sesuatu yang imajiner tetapi keberhasilan individu menjalani proses hidup ditentukan secara dominan oleh moral yang dimiliki.

Kurikulum Pendidikan Agama Islam berperan penting mengarahkan hasil capaian. Kurikulum Pendidikan Agama Islam secara umum meliputi, akidah (keyakinan), syariah (aturan keislaman) dan akhlak (perilaku manusia) (Noorzanah, 2017: 68; 74). Berbagai sekolah di berbagai propinsi di Indonesia mempunyai beragam kondisi sosial budaya. Oleh karenanya dibutuhkan berbagai penelitian ranah Pendidikan Agama Islam secara berkelanjutan untuk mengukur hasil capaian kurikulum dan proses belajar. Kemudian akan terlihat kemajuan atau kemund uran suatu pola pendidikan Agama di suatu negara dalam kurun waktu tertentu.

\section{METODOLOGI}

Bagian ini menjelaskan tentang: (1) rancangan penelitian; (2) sumber data; (3) teknik pengumpulan data; (4) dan analisis data. Untuk penelitian yang menggunakan alat dan bahan, perlu dituliskan spesifikasi alat dan bahannya. Spesifikasi alat menggambarkan kecanggihan alat yang digunakan, sedangkan spesifikasi bahan menggambarkan macam bahan yang digunakan.

Untuk penelitian kualitatif seperti penelitian tindakan kelas, etnografi, fenomenologi, studi kasus, dan lain-lain, perlu ditambahkan kehadiran peneliti, subjek penelitian, informan yang ikut membantu beserta cara-cara menggali data-data penelitian, lokasi dan lama penelitian serta uraian mengenai pengecekan keabsahan hasil penelitian.

Metode Penelitian yang digunakan yaitu studi literatur dengan tipe penelitian kualitatif dengan pendekatan kajian analitis literatur. Metode ini menggunakan telaah pustaka. Berbagai sumber pustaka ditelaah untuk saling memperkuat deskripsi yang dipaparkan. Penelitian sebelumnya sebgai sumber info terhadap perkembangan dari kajian penelitian Pendidikan Agama Islam. Kemudian dari penelitian-penelitian tersebut digunakan sebagai dasar kajian penelitian ini. 
Analisis data menggunakan cara perbandingan berbagai literatur dilakukan secara obyektif, sehingga hasil penelitian ini dapat menjadi referensi bagi penelitian selanjutnya dan memperkaya dibidang penelitian Pendidikan Agama Islam.

\section{HASIL DAN PEMBAHASAN}

Keberhasilan proses Pendidikan Agama Islam bergantung dari banyak hal. Sistem pendidikan yang diterapkan di sekolah dengan standarisasi dengan sistem negara mempunyai tujuan untuk mendapatkan hasil output yang mirip, meskipun hasil yang seragam tidak akan pernah didapatkan. Meskupun demikian usaha maksimal untuk mendapat kualitas terbaik pendidikan terus diupayakan. Setiap individu warganegara berasal dari keluarga yang berbeda dengan nilai-nilai yang ditanamkan oleh keluarga masing-masing.

\section{Pendidikan Agama Islam di Keluarga Berbasis Keteladanan}

Sebelum memasuki Pendidikan Agama Islam secara formal di sekolah para siswa telah mendapatkan Pendidikan Agama Islam dari keluarga masing-masing. Keadaan keluarga yang beraneka ragam jenis pekerjaan, tingkat pendapatan, perbedaan budaya dan sosial masyarakat akan berakibat tipe pemikiran yang berbeda bagi anggota keluarga tersebut. Pola pemikiran dari keluarga inilah yang akan dibawa oleh anak ke dunia luar atau ke kehidupannya di kemudian hari. Karakter dari keluarga masing-masing akan memberi bentuk atau pengaruh karakter dominan, sedangkan sekolah memberi peran melengkapi karakter asal dari individu tersebut.

Manusia dalam fase kehidupannya melewati berbagai masa. Setiap masa tumbuh kembang fisik dan mental yang sering dikategorikan dalam batasan umur mempunyai rentang kondisi psikologis yang berbeda-beda. Masa kecil, masa remaja, masa dewasa, masa tua. Masa-masa perubahan tersebut merupakan perubahan fisik atau badan sekaligus perubahan psikologis. Selama masa tersebut jenjang pendidikan yang dilalui juga berbeda. Dimulai dari pendidikan Taman KnakKanak (TK), Sekolah Dasar (SD), Sekolah Menengah Pertama (SMP), Sekolah Menengah Atas (SMA) dan Sekolah Tinggi. Pendidikan Agama yang diperoleh dari tiap tingkat sekolah (Saerozi, 2014: 39; 58).

Pendidikan di rumah didominasi oleh nilai-nilai keteladanan dari keluarga. (Shodiqoh dan Lisaniyah, 2020: 12; 29). Sedangkan dari sekolah nilai-nilai yang diharapkan diatur dalam kurikulum. Di sini peran kurikulum membantu proses pembelajaran di sekolah, memberi arahan Pendidikan Agama Islam bagi siswa di sekolah masing-masing, kemudian dilanjutkan di jenjang mahasiswa di perguruan tinggi. Kurikulum akan membantu proses evaluasi dari proses pembelajaran sehingga keberhasilan proses Pendidikan Agama Islam yang terukur.

Kewajiban pemeluk Agama Islam di gambarkan dalam 5 (lima) Rukun Islam. Rukun Islam memerintahkan (1) syahadat, bersaksi bahwa Allah SWT adalah Tuhan Yang Esa dan Muhammad 
SAW sebagai Rasulullah terakhir penutup para Nabi, (2) Kewajiban shalat lima waktu, (3) Kewajiban puasa, (4) Kewajiban zakat dan (5) Kewajiban haji. Dasar perintah agama Islam ini di ajarkan dan dicontohkan pertama-tama dari lingkungan keluarga. Nilai yang terdapat dalan rukun Islam ini adaalh nilai ketuhanan dan kemanusiaan.

Rukun Islam memerintahkan kepada penganutnya (muslim) selain menyembah kepada ALLAH SWT, juga berkewajiban menghormati dan peduli kepada sesama manusia. Hal itu tercermin pada Rukun Islam yang ke empat yaitu kewajiban membayar zakat. Zakat, selain zakat fitrah yang dibayarkan ketika bulan puasa Ramadan, masih terdapat zakat mal. Pembayaran zakat fitrah sebagai bukti rasa kemanusiaan dengan berbagi kebutuhan pokok seperti beras untuk mereka yang membutuhkan. Tindakan membayar zakat ini sesuai dengan pengamalan Pancasila sila 2 dan sila 5. Sila ke-2 yaitu kemanusiaan yang adil dan beradap. Saling membantu saudara sebangsa merupakan contoh tindakan kemanusiaan. Sila ke-5 yang mendorong keadilan sosial juga tergambar dalam pembayaran zakat ini, yaitu Keadilan Sosial bagi seluruh rakyat Indonesia.

Keteladanan dari keluarga akan memberi pengaruh dominan bagi karakter anak. Keluarga dengan rutinitas menjalankan perintah agama Islam akan memiliki karakter lebih baik dari keluarga yang abai terhadap ajaran agama. Karakter lebih baik yang dimaksud antara lain lebih bisa mengontrol emosi, mudah menyesuaikan bekerja dalam tim, mempedulikan lingkungan atau memiliki karakter kepemimpinan. Berdasarkan penelitian dari (Sunarni dan Rosita, 2018), keteladaan orang tua, ibu dan ayah pada fase awal kehidupan anak akan terbawa terus hingga proses kehidupan selanjutnya sang anak. Perilaku ini pun akan dibawa oleh anak pada kehidupan rumah tangga selanjutnya. Seperti yang kita ketahui bahwa keluarga adalah organisasi terkecil suatu negara yang mencetak kualitas anak bangsa. Oleh karenanya penting bagi negara memperhatikan kesejahteraan keluarga sebagai tempat tumbuh kembang awal generasi bangsa.

\section{Pendidikan Agama Islam di Sekolah Berbasis Kurikulum}

\section{A. Sejarah Kurikulum}

Kata kurikulum diambil dari bahasa latin curriculum yang terdiri dari kata curro atau curere dan ula atau ulums. Kata-kata tersebut bisa diartikan sebagai lapangan pacuan kuda atau jarak tempuh untuk perlombaan lari (Syaifuddin, 2009 dalam Wafi, 2017). Jika dilihat dari pengambilan asal kata tersebut kurikulum ditujukan sebagai sarana untuk mendapatkan hasil terbaik dari proses pembelajaran. Sarana ini harus dipersiapkan sebaik-baiknya jika perlukan suatu perbaikan secepatnya maka harus dilakukan. Hal-hal yang terkait untuk mendapatkan hasil terbaik antara lain guru atau tenaga pengajar, perlengkapan pembelajaran dan metode (Noorzanah, 2017: 68 ; 74).

Kurikulum Pendidikan Agama Islam secara umum meliputi akidah (keyakinan), syariah (aturan keislaman) dan akhlak (perilaku manusia). Sistem Pendidikan Agama diatur pada Undang- 
Undang Nomor 2 tahun 1989 tentang Pendidikan Nasional juncto Undang-Undang Nomor 20 tahun 2003 tentang tujuan Pendidikan Nasional, pengembangan muatan kurikulum, dan hak peserta didik (UU Nomor 20 tahun 2003 dalam Mu'ti, 2016). Kurikulum menjadi pedoman yang mengarahkan hasil dari proses pembelajaran terukur. yang diharapkan negara untuk menandai masyarakat yang sesuai dengan sila pertama yaitu Berketuhanan yang Maha Esa.

\section{B. Kurikulum Pendidikan Agama Islam}

Pembahasan tentang pendidikan Indonesia, peran guru dan sistem pendidikan merupakan variabel penting, sedangkan kurikulum di dalam sistem tersebut. Tambak et al., (2020) melakukan penelitian mengenai keprofesionalan guru masdrasah, artikel tersebut memaparkan pentingnya internalisasi nilai-nilai Pendidikan Agama Islam melalui praktek pelaksanaan perintah-perintah agama dengan mengistilahkan integrasi nilai Islam dalam pembelajaran. Seperti praktik salat berjamaah, pembiasaan salat dhuha dan lainnya. Sehingga kemudian yang diharapkan adalah akhlak yang mulia bagi siswa-siswa tersebut.

Kurikulum pembelajaran yang mendasari aktualisasi diri para siswa diuraikan sebagai berikut:

(1) Akidah

Akidah berasal dari bahasa Arab al-'aqdu yang berarti ikatan. Jika dilihat dari segi terminologi mempunyai arti teguh. Akidah (keimanan) merupakan pondasi sebagai muslim. Mengimani bahwa ALLAH adalah Tuhan yang satu, tiada Tuhan selain Dia, kemudian menyakini Muhammad adalah Rasul yang diutus ALLAH. Penanaman akidah bertujuan untuk memperkuat keyakinan dan jati diri sebagai muslim. Kesadaran menjadi muslim akan menuntun pada kesadaran untuk melaukan kewajiban sebagai muslim. Pengamalan Ajaran Islam perlu dilakukan dengan didasari oleh kesadaran individu dan keikhlasan dalam melakukan kewajiban tersebut. Kesadaran akan kewajiban terhadap Tuhan dan kewajiban terhadap manusia sebagai konsekuensi menjadi muslim.

Ajaran Islam secara garis besar tentang hubungan manusia dengan Tuhan (habluminallah) dan hubungan manusia dengan manusia (habluminannas). Kebaikan yang dilakukan pun sebenarnya untuk diri sendiri. Ajaran Islam yang Rahmatilil alamin (membawa kebaikan untuk Alam semesta beserta isinya) semestinya diamalkan sebagai pembuktian identitas kemusliman. Muslim yang senantiasa berusaha mengamalkan ajaran Islam oleh lingkungan sekitarnya akan digolongkan sebagai muslim dengan akhlakulkarimah (muslim bersifat baik).

Akidah yang terjaga dan selalu diperkuat akan memberi efek akhlak yang baik (akhlakul karimah). Dasar-dasar akidah sebenarnya sudah diterima oleh murid dari lingkungan keluarga masing-masing. Keteladan oarang tua dalm melaksanakan hukum-hukum Agama. Kemudian sekolah melalui kurikulum berperan memperkuat pemahaman para murid tersebut. 
(2) Fiqih

Fiqih secara bahasa mempunyai arti paham. Fiqih islam menyangkut semua kehidupan muslim. Sumber-sumber fiqih Islam yaitu Quran, Hadist, ijma, Qiyas. Fiqih atau hukum Islam secara garis besar menerangkan tentang hubungan antara manusia dengan Tuhan dan hubungan manusia dengan manusia.

Suatu aturan yang jelas, tegas dan adil dibutuhkan oleh manusia karena membantu menata kehidupan sosial masyarakat. Mata pelajaran tentang norma, aturan, hukum dalam sekolah sebagai gambaran miniatur kehidupan nyata bagi murid. Sebagai makhluk sosial yang sedang tumbuh dan mencari jati diri, maka murid memerlukan suatu gambaran dan pelatihan yang berkelanjutan sehingga memantapkan kepercayaan diri murid untuk menerima fakta bahwa mereka adalah makhluk sosial.

Hukum-hukum Islam merupakan jalan penolong manusia untuk melaksanakan fitrahnya. Adanya hukum akan mengatur keadaan yang bertujuan pada keadilan bersama. Fiqih yang ada di Islam dilaksanakan untuk kebaikan penganutnya.

(3) Quran dan Hadist

Quran sebagai kitab suci agama Islam diturunkan dan diajarkan kepada pemeluknya melalui Nabi Muhammad SAW. Hadist merupakan tindakan dan ucapan Rasullullah SAW. Dua pedoman ini yang digunakan oleh muslim dalam menjalankan keseharian hidup. Quran sendiri memiliki sejarah panjang, mulai dari diturunkan secara berangsur-angsur hingga disatukan menjadi sebuah buku. Setiap ayat di Quran memiliki sejarah yang mengikuti (asbabul nuzul). Demikian pula hadist, peristiwa dan riwayat hadist dilakukan oleh periwayat (perawi) yang telah terbukti kejujuran dan memilik keilmuan yang mumpuni untuk meriwayatkan.

Quran dan hadist mengatur berbagai macam hukum kehidupan muslim. Mulai dari hubungan manusia dengan Tuhan (ALLAH SWT), manusia dengan manusia, hingga manusia dengan isi alam semesta. Quran menjadi keajaiban kandungannya telah menjadi petunjuk berbagai manusia, bukan hanya muslim saja yang mempercayai Quran dengan berbagai informasi yang dikandung telah terbukti kehebatannya. Dunia barat yang terkagum akan sains membuktikan Quran sebagai sumber sains. Contoh, ketika dunia penelitian Barat menemukan tubuh Firaun dalam bentuk mumi yang diawetkan oleh garam, sebenarnya kita umat muslim sudah diinformasikan terlebih dahulu dalam Quran bahwa jasad Firaun akan ditemukan dalam kondisi utuh (terawetkan).

(4) Sejarah Islam (Tarikh dan Peradaban Islam)

Sejarah Islam mempunyai peran penting yaitu memberi gambaran kepada generasi penerusnya bagaimana Islam disebarkan dari jazirah Arab hingga ke berbagai belahan dunia. Hal ini 
akan berperan menumbuhkan loyalitas kepada keyakinan. Kebanggaan tersebut akan memberi semangat pemeluk untuk maksanakan ajaran Islam yang Rahmatilil alamin (membawa kebaikan untuk Alam semesta beserta isinya). Nas, (1987) dalam Hilgendof (2009) memaparkan bahwa selama 1000 tahun Islam telah membuktikan kontribusinya pada berbagai kehebatan. Berbagai disiplin ilmu, intelektual, mulai dari filsafat, geometri, kedokteran, optik, fisik dan lainnya. Kemajuan dunia pengetahuan sekarang merupakan bagian kontribusi Islam.

Islam sebagai suatu keyakinan akan sulit diterima oleh manusia di berbagai belahan Bumi yang terdiri atas beragam warna kulit dan budaya jika nilai-nilai yang dibawa bertentangan dengan nilai humanitas manusia. Sejarah dunia membuktikan bahwa Muhammad SAW sebagai Rasulullah, Nabi terakhir dan penutup telah membuktikan kepemimpinannya atas Islam yang diakui dunia Timur dan Barat.

Krisis jati diri yang sedang melanda anak muda dunia dikarenakan ketidaktahuan akan sejarah diri dan bangsanya. Kemajuan teknologi informasi mempunyai kebaikan dan keburukan bagi masing-masing generasi muda di setiap negara di dunia. Generasi yang rentan terhadap kemajuan ini adalah remaja, karena mereka sedang tumbuh mencari jatidiri. Berdasar hal ini, maka menjadi penting sejarah identitas keyakinan, seperti identitas Sejarah Agama Islam untuk diketahui sejak dini oleh murid melalui pelajaran di sekolah.

Bahasa Arab merupakan bahasa ketiga yang digunakan oleh penduduk Bumi. Seperti halnya bahasa Inggris, yang merupakan bahasa yang paling banyak dilaflkan oleh manusia. Hal ini dikarenakan bangsa Inggris merupakan penjelajah, mengarungi samudra untuk menemukan tanah baru yang dimaksudkan mendukung kebutuhan negaranya, Britania Raya. Demikian pula bangsa Arab, sebelum terbagi seperti sekarang dengan beragam negara, sejarah mereka menunjukkan bahwa berdagang ke berbagai negara merupakan tradisi sosial mereka. Hal ini pula yang membantu persebaran Agama Islam dan bahasa Arab sehingga saat ini termasuk bahasa dunia.

(5) Akhlak

Ahk lak merupakan tidakanan sebagai gambaran hasil dari pemahaman seseorang terhadap suatu norma. Pemahaman terhada prkatek kemanusiaan. ajaran Agama Islam akan meuntun pada Akhlak atau perilaku orang dengan pandangan bijaksan akan berbeda dengan orang yang suka sembarangan bersikap. Akhlak muslim menunjukkan karakter keimanan. Masyarakat seringkali menggambarkan orang dengan akhlak baik dikatakan memiliki pemahaman agama baik.

Pendidikan Agama Islam sebagai salah satu cara membentuk akhlak siswa dalam lingkungan sekolah. Akhlak akan terbangun karena kebiasaan yang menerus. Mengingat sekolah yang menerapkan Pendidikan Agama Islam sudah dimulain secara resmi oleh negara dari tingkat sekolah Dasar (SD) hingga Perguruan Tinggi. Pembentukan moral generasi bangsa oleh negara 
melalui Pendidikan formal sekolah negeri dan sekolah privat akan membentuk perilaku masyarakat yang mendukung nilai-nilai bangsa Indonesia. Peran akhlak untuk kehidupan bernegara memberikan tantangan bagi Kurikulum Pendidikan Agama Islam secara menerus dari semua tingkat pendidikan. Berbagai etnis, budaya yang dimiliki Indonesia tentunya membutuhkan adaptasi pada pola pengajaran dan penyampaian kepada masing-masing masyarakat sesuai dengan kebudayaan lokal yang ada dari Sabang hingga Merauke.

\section{Kebutuhan Pendidikan Agama di Negara Sekuler sebagai Pembanding Kurikulum di Indonesia}

Indonesia mempunyai penduduk dengan mayoritas beragama Islam, tetapi Indonesia bukan negara agama. Indonesia negara yang menghormati pemeluk agama yang di atur pada UUD 1945 pasal 29 ayat 2 bahwa Negara menjamin kemerdekaan tiap-tiap penduduk untuk memeluk agama. Sehingga secara resmi Islam tidak dianggap sebagai satu-satunya agama yang diakui negara. Terdapat agama lain seperti Hidu, Budha, Kristen dan kepercayaan.

Kebutuhan pendidikan agama di negara sekuler dan negara yag bukan sekuler berbeda misalnya dalam tata laksana karena tujuan yang ditarget berbeda pula. Bahkan antar negara-negara sekuler pun memiliki cara pengelolaan pendidikan agama yang berbeda. Pendidikan Agama secara resmi di perguruan tinggi dan sekolah tinggi tidak diberikan secara formal seperti halnya di tingkat sekolah sebelum sekolah tinggi. Meski pun demikian mahasiswa yang memiliki keyakinan (beliefs) atau agama (religious) memiliki kesehatan mental yang lebih baik. Kesehatan mental yang lebih baik akan mengarahkan pada peningkatan kapasitas individu untuk sukses ke kehidupan selanjutnya (Melnyk, et al., 2014). Kesehatan mental ini memberi pengaruh pada kualitas individu sebagai warga suatu negara. Ketika warganegara berkualitas baik maka secara langsung akan berpengaruh pada kualitas negara. Negara-negara sekuler menghormati para pemeluk kepercayaan dan agama ada karena dampak positif yag diberikan kepada negara tersebut.

Genc, Avest, dan Miedema (2011), melakukan penelitian Pendidikan Agama (Religious Education) pada negara sekuler Turki dan Belanda. Turki memberikan Pendidikan Agama dibawah pengawasan Kementrian Pendidikan dan mulai diterapkan sejak tingkat sekolah dasar pada tahun 1949, diikuti setingkat sekolah menengah pertama (SMP) pada 1956 dan setingkat sekolah menengah atas (SMA) pada 1967. Hal ini dimulai setelah perang dunia ke-2. Sebelumnya hampir 2 dekade Pendidikan Agama dilarang. Pendekatan kurikulum yang digunakan di Turki disebut Religious Culture and Knowledge of Ethnic. Sebagai negara sekuler bahasan tentang Religious Culture and Knowledge of Ethnic di Turki tidak dikhususkan untuk Islam, tetapi untuk kepercayaan dan agama yang dilindungi oleh Undang-Undang negara Turki. Meskipun demikian, pemerintah Turki tetap memberikan bantuan dana dan membina kegiatan spiritual keagamaan melalui masjid. 
Sehingga bisa dikatakan negara secara tidak langsung tetap memantau kegiatan keagaamaan. Berbeda lagi Pendidikan Agama di negara sekuler lain, seperti Belanda. Pendidikan agama di Belanda bisa dikatakan baru mulai secara ekplisit pada 1985 dengan program bernama Religious and Ideological Movement. Kemudian Gopinathan, S. (1995) memaparkan tentang Pendidikan Agama di negara Sekuler Singapura, bahwa Kementrian Pendidikan Singapura mengumumkan pada 1984 dimulainya kurikulum Religious Knowledge lebih intens untuk jenjang sekolah umur 14-16 tahun.

Inggris sebagai negara sekuler melalui Brtitish Council bagian Diversity Unit memaparkan pentingnya penghormatan pada perbedaan beragama dan berkeyakinan (berkepercayaan). Penghormatan ini mempengaruhi kestabilan suatu negara karena suatu keyakinan (beliefs) atau agama (religious) merupakan hak asasi manusia. Hak asasi merupakan kebutuhan dasar manusia dan secara alami manusia akan memperjuangkan hak asasi mereka. Perjuangan hak asasi ini seringnya ditempuh dalam suatu kelompok (perkumpulan). Jaminan atas hak asasi ini akan mengarah pada jaminan keamanan suatu negara.

Negara sekuler seperti Inggris memberi ruang kepada pendudukyan untuk memiliki kepercayaan (beliefs) atau agama (religious) menunjukkan peran pentingnya dalam kehidupan manusia. Pemerintah Inggris melihat bahwa kepercayaan (beliefs) atau agama (religious) mempunyai peran penting bagi individu, komunitas bahkan memberi pengaruh lebih luas yaitu bagi suatu negara. Penghormatan diberikan kepada mereka yang memegang dan menjalani kepercayaan (beliefs) atau agama (religious) tersebut. Kebutuhan hak asasi ini seringkali menajdi masalah sensitif yang mempengaruhi politik negara. Jadi, akan menjadi hal aneh jika suatu negara mengalami kemunduran penghormatan terhadap Hak Asasi beragama padahal mayoritas penduduknya beragama bahkan beragama dilindungi oleh Undang-undang Negara.

Berdasar Hak Asasi Manusia akan kebutuhan dasar dan efek besar yang akan dihasilkan, maka negara-negara sekuler pun memberi tempat pada Pendidikan Agama di negaranya. Proses Pendidikan terbaik diberikan kepada warganegaranya dengan harapan peningkatan kualitas moral warganegara kemudian meningkat pada tataran negara.

Keyakinan (beliefs) dibutuhkan tidak hanya oleh mereka yang percaya kepada Tuhan, tetapi juga dibutuhkan oleh mereka yang menyebut diri sebagai ateis (tidak percaya Tuhan). Perbedaan antara mereka yaitu pada sudut pandang terhadap apa keyakinan tersebut. Ateis menganggap Tuhan itu tidak ada, keberadaan alam ini tercipta oleh hukum alam yang memang ada dengan sendirinya. Hukum-kum alam bekerja dengan sendirinya tanpa campir tangan Tuhan. Meskipun ateis mereka tetap membutuhkan suatu keyakinan (beliefs) terhadap proses di dalam kehidupan mereka yang didasarkan pada teori-teori alam. Pandangan psikologis menekankan kebutuhan manusia akan 
keyakinan (beliefs). Rasa yakin akan menuntun manusia memenuhi tujuan hidup yang diinginkan oleh manusia itu sendiri.

Negara sekuler, mengijinkan bahkan mendukung warga negaranya meemiliki suatu kepercayaan (beliefs) atau agama (religious). Negara-negara sekuler ini tetep saja memberikan kebebasan beragama dalam kehidupan pribadi masyarakatnya. Jika tidak maka akan terjadi ketidakseimbangan psikologis yang berefek pada kesehatan jasmani manusia tersebut. Karena pembuktian secara ilmiah bahwa manusia sebagai makhluk tercipta dengan sifat dasar yang harus dipenuhi sepanjang hidupnya untuk memilih keyakinan. Keyakinan (beliefs) ini akan memberikan tipologis individu yang percaya diri bahwa jalan yang dipilih dengan kesadaran dan segala tantangan yang ada akan dihadapi dengan percaya diri. Ketika individu tersebut memilih jalan keyakinan ateis (tidak mempercayai Tuhan), maka itulah keyakinan tersebut sebagai suatu pilihan. Oleh karena itu pendidikan agama sebagai salah satu pendidikan yang menentukan kemajuan bangsa untuk menciptakan generasi yang sehat secara spiritual yang kemudian mendorong ke kesehatan jasmani.

\section{Pendidikan Agama Islam di Negara Non-Sekuler}

Malaysia merupakan negara dengan mayoritas penduduk agama Islam seperti Indonesia. Bedanya, agama Islam di Malaysia sebagai agama resmi negara dengan tetap memberi tempat agama lain untuk dianut warganegaranya. Pendidikan Agama Islam di bawah pengaturan Negara Bagian Federal Malaysia. Pembelajaran Pendidikan Agama Islam diberikan di sekolah-sekolah formal dan sekolah privat (Lubis, 2017: 1 ; 12). Komunitas Islam sebagai mayoritas memiliki pengaruh terhadap kehidupan politik negara, sehingga negara Malaysia merasa penting memberi kontrol kepada warganegaranya melalui Pendidikan Agama Is lam. Nilai-nilai Islam yang Rahmatilil alamin (membawa kebaikan untuk Alam semesta beserta isinya) diharapkan menuntun perilaku masyarakat mayoritas kemudian membawa pada kejayaan negara (Zamri, 2019: 29 ; 48).

Indonesia bukan negara agama, tetapi pelaksanaan pendidikan Agama diatur sendiri oleh Kementrian Agama secara terpusat. Pendidikan Agama Islam ditempuh oleh semua siswa yang beragama Islam. Peserta Pendidikan Agama Islam berasal dari latar belakang beragam dan mempunyai tingkat keyakinan dan tingkat pengamalan Agama Islam yang berbeda-beda. Tujuan jangka panjang yang diharapkan dari Pendidikan Agama Islam di Indonesia tertuang pada UndangUndang Nomor 2 tahun 1989 tentang Pendidikan Nasional juncto Undang-Undang Nomor 20 tahun 2003 tentang tujuan Pendidikan Nasional, penegembangan muatan kurikulum, dan hak peserta didik. Tujuan dan fungsi Pendidikan Agama Islam Indonesia yang dijabarkan melalui UndangUndang Sistem Pendidikan Nasional UU nomor 20 tahun 2003 yaitu, membentuk dan mengembangkan karakter dan peradaban bangsa dalam konteks intelektual yang bertujuan 
mengembangkan potensi siswa untuk menjadi orang beriman, dan memiliki rasa takut akan Tuhan Yang Maha Esa (UU Nomor 20 tahun 2003 dalam Mu'ti, 2016).

Penelitian di negara Islam Iran oleh Geinaghi, (2018) memaparkan hubungan yang signifikan antara optimisme dan dukungan sosial. Optimisme ini dimiliki oleh responden yang memiliki keyakinan dan pengamalan agama yang baik.

Pengajaran dan pengamalan Agama yang baik diperoleh dari perjalan panjang pembinaan dari keluarga dan negara. Negara melalukan pembinaan agama lewat instrumen pendidikan melalui Pendidikan Agama Islam kemudian diiuti oleh kegiata-kegiatan pendukungnya. Perkembangan teknologi informasi yang begitu cepat ini membutuhkan penanganan secepat pula. Budaya luar yang tidak sesuai dengan budaya kita akan melunturkan budaya Indonesia secara pelan tapi pasti. Pendidikan Agama Islam sebagai salah satu bendeng terutama untuk anak anak muda usia sekolah penting untuk terus dievaluasi.

Berbagai penelitian dibutuhkan untuk melihat berbagai fenomena sistem pendidikan Agama Islam yang relevan dengan jaman dan pengarunya terhadap para murid. Tentu saja peran pemerintah sebagi pemangku kebijakan sangat dibutuhkan. Kurikulum Pendidikan Agama Islam membutuhkan dukungan penelitian-penelitian yang mengikuti perkembangan jaman. Pembenahan secara menerus untuk beradaptasi dengan jaman dikarenakan pengaruh teknologi memepengaruhi perilaku manusia, dalam kontek ini adalah murid sebagai subyek.

\section{PENUTUP}

\section{Kesimpulan}

Pendidikan Agama Islam mempunyai peran penting di Indonesia sebagai bekal moral yang menentukan kemajuan negara Indonesia mengingat pemeluk Islam sebagai mayoritas. Mayoritas memiliki arti mempengaruhi seperti kerukunan dan kesejahteraan dalam skala besar atau dominan. Pendidikan Agama Islam melalui lembaga formal sekolah ditargetkan sebagai penguat moral generasi masa depan Indonesia, yang pendidikan moral secara nonformal dilakukan oleh lingkungan keluarga masing-masing. Diperkuat oleh Pasal 3 Undang-Undang Nomor 20 tahun 2003 yang intinya memaparkan tentang sistem Pendidikan Nasional yang bertujuan untuk berkembangnya potensi peserta didik agar menjadi manusia yang beriman dan bertakwa kepada Tuhan Yang Maha Esa disertai akhlak mulia. Kebutuhan Pendidikan Agama dilakukan pula oleh negara sekuler karena penelitian membuktikan bahwa keyakinan (beliefs) atau agama (religious) memberi dukungan positif pada kualitas individu, seperti optimisme masa depan dan kehidupan sosial yang lebih baik. Kemudian individu-individu unggul tersebut akan meningkatkan kapasitas negara. 
Kearifal lokal dalam pola Pendidikan Agama Islam akan membantu tingkat keberhasilan target pendidikan. Kemajemukan masyarakat sebagai studi Perencanaan Kurikulum Pendidikan Agama Islam penting ditinjau berdasar konsisi sosial budaya bangsa ini. Peran pemerintah selalu pemangku kebijakan dan kerjasama dari masyarakat akan menentuk lan keberhasilan capaian Pendidikan Agama Islam di Indonesia. Guna mencapai tujuan yang dipaparkan di atas maka kurikulum yang matang sesuai kepentingan pendidikan dan kebutuhan bangsa semestinya dilaksanakan. Perubahan politik di Indonesia tidak boleh berpengaruh pada kebijakan penerapan kurikulum pendidikan Agama Islam. Kurikulum yang berubah-ubah dan bergantung pada politik akan membuat kualiutas Pendidikan Agama Islam merosot.

\section{DAFTAR RUJUKAN}

Dhaifi, Ahmad. 2017. Perkembangan Kurikulum Pendidikan Agama Islam di Indonesia. Jurnal Edureligia, Volume 1, Nomor 1, Halaman: 76-88.

Geinaghi, Akram, Akram Sanago, and Leila Joubary. 2018. The Relations between Beliefs, Social Support and Optimisme inStudents of Golestan University in Medical Sciences". Journal of Medical Education, Volume1, Nomor 2, Halaman: 26-29.

Genc, Muhammad Fatih, Ina ter Avest, and Siebren Miedema. 2011. Religious Education in Two Secular Multicultural Societies: Turkish and Dutch case Compared. Procedia Social and Behavioral Sciences 15 Halaman : 801-805.

Hasan, Mochamad Sya'roni. 2017. Pengembangan Kurikulum Pendidikan Agama Islam Terpadu di Sekolah. Jurnal Al-Ibrah Volume 2 Nomor 1 Halaman : 60-87.

Hidayati, Wiji. 2016. Manajemen Kurikulum Pendidikan Agama Islam dan Budi Pekerti Jenjang SMA Bermuatan Keilmuan Integrasi Interkoneksi. Manageria: Jurnal Manajemen Pendidikan Islam Volume 2, Nomor 1, Halaman: 195-225.

Ibnu Khaldun, Abdurahman. 2003. Muqaddimah Ibnu Khaldun. Beirut: Dar al-Kutub al-'Ilmiyyah”.

Khoiri, Miftahul. 2020. Pengembangan Pendidikan Agama Berbasis Budaya Sekolah dalam Mengatasi Problematika pendidikan Agama. Tarlim Jurnal Pendidikan Agama Islam Volume 3. Nomor 1 Halaman: 39-50.

Lubis, Syaiful Akhyar. 2017. Islamic Education in Indonesia and Malaysia: The Existance and Implementation until 20th Century". Edukasi: Jurnal Penelitian Agama dan Keagamaan Volume 15, Nomor 1 Halaman 1-12.

Mahfud, Choirul. 2019. Evaluation of islamic education curriculum policy in Indonesia. Premiere Educandum: Jurnal Pendidikan Dasar dan Pembelajaran Volume 9 Nomor 1 Halaman : 34 43.

Melnyk, Bernadette Mazurek, Caitlin Selvin, Lisa Millitelo, Jacqueline Hoying, Alice Teall, and Colleen McGover. 2014. Physical Health, Lifestyle Beliefs and Behaviors, and Mental Health of Entering Graduate Health Professional Students: Evidence to Support Screening and Early 
Intervention. Journal of the American Association of Nurse Practisioners 28 Halaman: 204211.

Mu'ti, Abdul. 2016. Akar Pluralisme dalam Pendidikan Muhammadiyah". Jurnal Afkaruna Volume 12. Nomor 1 Halaman: 1-42.

Noorzanah. 2017. Konsep Kurikulum dalam Pendidikan Agama Islam. Jurnal Ittihad Volume 15, Nomor 28 Halaman: 68-74.

Pelupessy-Wowor, Jennifer. 2016. The Role of Religious Education in Promoting Religious Freedom: A Mutual Enrichment Between 'My Story,' 'Your Story,' and 'Our Stories'." The Review of Faith \& International Affairs 14.4 Halaman :98-106.

Rustan, Edhy, Nurul Hanifah, and Bulu' Kanro. 2018. De-radicalization in the Implementation of Islamic Education Curriculum in SMA Masamba South Sulawesi. Jurnal Dinamika Ilmu Volume 16. Nomor2 Halaman :271-283.

Saerozi, Muhammad. 2014. Historical Study on The Changes of Religious and Moral Education in Indonesia. Journal of Indonesian Islam Volume 8. Nomor 1 Halaman: 39-58.

Shodiqoh, Mira dan Fasihatul Lisaniyah. 2020. Menejemen Pendidikan Agama Islam dalam Keluarga. Jurnal Tadris, vol 14, No. 22, Halaman $12-30$

Sukardi, Ismail. 2016. Character Education Based on Religious Values: an Islamic Perspective. Ta'dib: Journal of Islamic Education Volume 21 Nomor 1 Halaman : 41-58.

Sunarni, Dwi Hayantina dan Tita Rosita. 2018. The Parent Role in Early Childhood in Character Building (Descriptive Studi at SPS Dahlia Desa Sundawenang Kecamatan Parungkuda Kabupaten Sukabumi)". Jurnal Empowerment Volume 7. Nomor2 Halaman: 319-327.

Supriadi, Cecep. 2015. Relasi Islam dan Negara: Wacana Keislaman dan Keindonesiaan”. Jurnal Kalimah Volume 13. Nomor 1 Halaman: 199-221.

Syah, Muhammad Noor Sulaiman. 2016. "Challenges of Islamic Education in Muslim World: Historical, Politic and Socio-cultural Perspective" Qudus International Journal of Islamic Studies Volume4.Nomor1 Halaman: 82-105.

Sya'bani, Mohammad Ahyan Yusuf. 2018 Pengembangan Kurikulum Pendidikan Agama Islam dalam Persfektif Pendidikan Nilai. Jurnal Tamaddun Volume 19. Nomor 2: 101-114.

Syihabuddin and Aam Abdussalam.2015. Islamic Education: Its Concept and Their Implementation in The Current Context. Tarbiya: Journal of Education in Muslim Society Volume 2. Nomor 1 Halaman : 23-34.

Wafi, Abdul. 2017. Konsep Dasar Kurikulum Pendidikan Agama Islam. Jurnal Edureligia Volume 1. Nomor 2 Halaman: 133-139.

Zamri, dan Abdul Mu'ati. 2019. From Inculcating Islamic Values To Rahmatan Lil Alamin": Promulgating Various Approches of Islam in Malaysia. Journal of Malay Islamic Studies Volume 3. No 2 Halaman: 29-48 